\section{Aquaculture}

Vol. 255, Issues 1-4 , 31 May 2006, Pages 223-232

http://dx.doi.org/10.1016/i.aquaculture.2005.12.006

(c) 2005 Elsevier B.V. All rights reserved
Archimer, archive institutionnelle de l'Ifremer http://www.ifremer.fr/docelec/

\title{
Impact of essential fatty acid deficiency and temperature on tissues' fatty acid composition of European sea bass (Dicentrarchus labrax)
}

\author{
A. Skallia ${ }^{a}$ J.H. Robin ${ }^{\text {b, }}$, N. Le Bayon ${ }^{b}$, H. Le Delliou ${ }^{b}$ and J. Person-Le Ruyet ${ }^{b}$ \\ aDepartamento Biología Animal y Ecología, Facultad de Ciencias Universidad de Granada, Spain \\ bUMR 1067, Nutrition Aquaculture Génomique des Poissons, Ifremer, Centre de Brest, BP 70, 29280 \\ Plouzané, France \\ *: Corresponding author : Tel.: +33 298 224387; fax: +33 298 224653; email: jrobin@ifremer.fr
}

\begin{abstract}
:
The effects of essential fatty acid deficiency and temperature on the fatty acid profiles of polar lipids $(\mathrm{PL})$ and neutral lipids (NL) from various tissues (muscle, liver, gills, eyes and brain) of European sea bass juveniles were compared in a two factorial design. Fish $(60 \mathrm{~g})$ were held for 84 days at 22 or 29 ${ }^{\circ} \mathrm{C}$ (upper limit for growth) and fed either at a lower or a higher level than $n-3$ HUFA minimal requirement for growth $(0.4 \%$ and $2.2 \% n-3$ HUFA dry matter for diets LD and HD, respectively). Essential fatty acid deficiency had a major influence on fatty acids in NL fraction of all tissues, a more moderate influence on PL of muscle, liver and gills, while a low and very low diet influence was observed on eyes and brain PL fatty acid content, respectively. DHA and EPA content in brain PL as well as DHA in eyes PL were not affected by diet. DHA contents were similar in gill PL of 22-HD, 29HD and 22-LD but was reduced in 29-LD fish. Most of brain PL fatty acids displayed a significant effect of temperature (at $29{ }^{\circ} \mathrm{C} ; 18: 0,18: 1 n-9$ contents were higher, and $20: 5 n-3,22: 6 n-3$, $20: 4 n-6$ contents were lower than at $22{ }^{\circ} \mathrm{C}$ ). Temperature had more influence on PL than on NL fatty acid content, except in liver. A lipogenic activity seemed to occur, both $16: 0$ and $18: 0$ were high particularly in liver NL and dependent on temperature (higher at 29 than at $22{ }^{\circ} \mathrm{C}$ ). An enhanced $18: 3 n-6$ content in fish fed on the deficient HUFA diet indicated a desaturation activity, mainly in liver NL and gill PL, with higher arachidonic acid content in PL of gills than other tissues. Muscle fatty acid profiles in NL and PL were more similar to those of whole body than other tissues, however total lipid content then PL : NL ratio differed. This study shown that beside known characteristics of each tissue in term of PL fatty acid content, each tissue have also characteristics in term of response to temperature and dietary deficiency influence. Among then, neural tissue displayed the highest capacity to regulate DHA content in PL, preserving functionality despite HUFA deficiency.
\end{abstract}

Keywords: European sea bass; $n-3$ HUFA; Temperature; Tissue fatty acid composition 


\section{Introduction}

The nutritional aspects of essential fatty acids (EFA) in fish have been widely investigated (Sargent et al., 2002; Tocher, 2003). The n-3 highly unsaturated fatty acid (n-3 HUFA) are required nutrients for marine fish (Kanazawa et al., 1979), mainly eicosapentaenoic acid (20:5n-3; EPA) and docosahexaenoic acid (22:6n-3; DHA). These fatty acids are major components of polar lipids in fish, insuring membrane functionality (Sargent et al., 2002). HUFAs are implicated in many physiological processes, including fish adaptation to environmental factors as temperature (Hazel et al., 1992; Farkas et al., 1994). However regulation of membrane fluidity may involve other components, as monounsaturated/saturated fatty acids ratio (Wodtke and Cossins, 1991) or cholesterol/phospholipid ratio (Robertson and Hazel, 1996).

In general, the main lipid source used in fish feeds is fish oil, contributing with fish meal to bring high n-3 HUFA content in diets. Replacement of fish oil by vegetable oil results in lower contents of EPA and DHA, and in higher contents of the 18C fatty acids (oleic, linoleic and linolenic acids) in all fish species (Alexis, 1997; Bell et al., 2001; Izquierdo et al., 2003; Regost et al., 2003). The fatty acid composition of fish tissue lipids usually reflect those of the dietary lipids (Jobling, 2001). The available data concerning the effects of temperature on tissues lipid composition in marine fish are related to low temperature (Ventrella et al., 1993; Staurnes et al., 1994), conversely the effects of high temperature are poorly documented. Although tissue fatty acid profiles can be modified by altering the sources of fats and oils in formulating fish feeds, little is known on the combined effects of temperature and dietary n-3 HUFA in tissue fatty acid profiles, mainly in marine fish.

The effects of two dietary n-3 HUFA contents ( 0.4 and $2.2 \% \mathrm{DM})$ and two stabilized temperatures $\left(22\right.$ and $\left.29^{\circ} \mathrm{C}\right)$ have been studied on feeding, growth, metabolism and body composition of juveniles sea bass (Person-Le-Ruyet et al., 2004a). These results showed that specific growth rate was significantly affected both by diet and temperature but there was no significant difference in final fish proximate composition except a decrease in moisture content with temperature. Whole body fatty acids were affected by diet and temperature with some interactions. This experiment was designed in order to follow how fish may adapt to temperature when they were fed under or over HUFA requirement level, this adaptation should be tissue dependent. Fish receiving enough HUFAs may adapt their tissues' polar lipids with less constrain than fish fed a deficient diet. A specific incorporation of n-3 HUFA in some tissues might also induce a reduced availability of HUFA for other tissues. The purpose of the present study was to investigate these hypothesis and to provide information on how these two factors influence fish fatty acid composition of target tissues: liver, muscle, gills, neural tissues (brain and eyes) after 84 days exposure under the four experimental conditions tested.

\section{Materials and methods}

\subsection{Experimental design}

The fish of two temperature groups $\left(22\right.$ and $\left.29^{\circ} \mathrm{C}\right)$ were fed to satiation with two experimental diets. Diets were formulated to be isonitrogenous and isolipidic, $50 \%$ 
crude protein and $16 \%$ crude lipid, and to contain $2.2 \%$ or $0.4 \%$ n-3 HUFA (HD and $\mathrm{LD}$, respectively). The two diets differed only by the oil added, details on diets composition can be found in Person-Le Ruyet et al. (2004a), dietary fatty acids were also presented compare to tissues fatty acids in Fig. 1 to 3 . The experiment was carried out using triplicate tanks of each group (LD-22, LD-29, HD-22, HD-29). At the end of the experiment (day 84), the fish were fasted for $24 \mathrm{~h}$ and six fish per tank were anaesthetised in a solution of ethylene-glycol-monophenyl-ether $(0.5 \%)$ before sampling. In each fish, different tissues were taken as follow: gills arch washed in $0.25 \mathrm{M}$ sucrose; whole liver; whole head; about $8 \mathrm{~cm}^{2}$ of dorsal muscle taken under the first dorsal fin and skin was removed. They were immediately frozen in nitrogen liquid and stored at $-80^{\circ} \mathrm{C}$ until analysis. The gill filaments, brain and eyes were selected prior to analyses.

\subsection{Analytical methods}

The lipid analyses of all tissues (pooled samples per tank) was done according to Folch et al. (1957), chloroform being replaced by dichloromethane. The separation of neutral lipids and phospholipids was performed according to the procedure described by Juaneda and Rocquelin (1985). A part of each sample was transmethylated according to Morrison and Smith (1964). Fatty acids methyl esters (FAME) were separated by gas chromatography as described previously in Person-Le-Ruyet et al. (2004a). FA composition was expressed as percent of total identified FA methyl esters.

\subsection{Data analysis}

All results are expressed as mean $\pm \mathrm{SE}$. Statistical analyses were conducted using Statistica ${ }^{\circledR}$ for Windows, data in \% being arcsin square-root transformed. For each fatty acid, differences between the four experimental conditions were tested by a two-way ANOVA, to identify the effects of temperatures and diets and their possible interactions. When significant interactions were observed, differences between means were compared by a Newman-Keuls test, differences were considered significant at $\mathrm{P}<$ 0.05 .

Similarities between fatty acid profiles between treatments within each tissue, or between tissues within treatments were studied using the coefficient of distance D (McIntire et al., 1969):

$$
D(h-j)=\left(\sum_{i=1}^{n}(P i h-P i j)^{2}\right)^{1 / 2}
$$

where the $D(h-j)$ is distance between treatments $h$ and $j$, and Pih and Pij are percentage of the fatty acid $i$ in treatments $h$ and $j$, for each $i$ fatty acid. 


\section{Results}

Neither diet nor temperature significantly affected lipid content in the muscle, gills, eyes and brain (Table 1). A significant interaction of the two factors studied was observed for liver, liver of 29-HD fish having lower liver fat content than those of 22-HD and 22-LD. A high variability was observed in muscle lipids in 22-LD and 29-HD groups.

The fatty acid (FA) composition of fish tissues is reported in Fig.1-3. Sum of the presented fatty acids account for 71 to $86 \%$ and 87 to $93 \%$ of identified fatty acids for NL and PL, respectively. Except in eyes PL and brain (PL, NL), palmitic acid (16:0) contents were significantly influenced by dietary contents (Fig.1). They were higher in fish tissues than in diets. Significant temperature influences were observed in whole body PL, muscle PL, in liver NL ( higher values at $29^{\circ} \mathrm{C}$ than at $22^{\circ} \mathrm{C}$ ), and brain NL (higher at 22 than $29^{\circ} \mathrm{C}$ ). No significant influence of diet was observed on stearic acid (18:0) contents.

Temperature induced significant differences in stearic acid contents of muscle and liver PL and NL, whole body NL, eyes NL and brain PL, with higher values at $29^{\circ} \mathrm{C}$ than at $22^{\circ} \mathrm{C}$. Conversely, in gills PL, 18:0 contents were lower at 29 than at $22^{\circ} \mathrm{C}$. Compared to diets, stearic acid contents were very high in all tissues, specially in PL and in brain NL. Oleic acid (18:1n-9) displayed various influences of diet and temperature with several interactions (in muscle PL, whole body NL and liver NL). In all tissues, except in brain PL, a significant influence of dietary 18:1n-9 was observed. Temperature induced higher 18:1n9 content at 29 than at $22^{\circ} \mathrm{C}$ in whole body PL, in muscle PL, gills PL and NL, and brain PL. Conversely, in liver NL 18:1n-9 contents were lower at 29 than at $22^{\circ} \mathrm{C}$ with an interaction (stronger temperature effect in LD than in HD groups).

The higher 18:2n-6 and lower 20:4n-6 contents of diet LD compared to HD, was reflected in all tissues studied (Fig. 2). A noticeable exception in diet influence was encountered for 18:3n-6; despite having lower amount in LD than in HD diets, fish fed LD showed higher levels of 18:3n-6 than fish fed HD, in both polar and neutral lipids of WB, muscle, liver and gills (ns in eyes and brain). A significant effect of temperature on 18:3n-6 in gills PL and muscle NL was observed, with lower values at 29 than at $22^{\circ} \mathrm{C}$. Compared to diets contents, high percentages of arachidonic acid (AA, 20:4n-6) were observed in polar lipids of all tissues analysed and in brain NL. Gills displayed higher AA contents than other tissues in polar lipids, a diet $\mathrm{x}$ temperature interaction occurred, with higher value at 29 than at $22^{\circ} \mathrm{C}$ only in fish fed HD. Significant effects of temperature were observed with higher AA content in muscle PL, and lower values in brain PL and whole body NL, at 29 than at $22^{\circ} \mathrm{C}$. Temperature also influenced $18: 2 \mathrm{n}-6$ contents with higher values in gills PL and whole body NL, and lower values in muscle PL and liver NL at 29 than at $22^{\circ} \mathrm{C}$.

In comparison with dietary levels, DHA contents were very high in all tissues PL, while 18:3n-3 contents were low (Fig. 3). A significant influence of diets was observed for n-3 FA in all cases except brain PL and 22:6n-3 in eyes PL. Eyes PL were very high in DHA, compare to other tissues including brain, EPA levels in brain and eyes PL were lower than the other tissues analysed. In all tissues NL, EPA and DHA levels were clearly reduced in LD groups compared to HD groups. Liver had lower levels of EPA and DHA in NL than other tissues. The highest levels of DHA in NL were encountered in brain even within LD fed fish. Among temperature significant lower values at 29 than at $22^{\circ} \mathrm{C}$ were 
found for 18:3n-3 in WB, muscle, liver, eyes PL, and in liver NL; for EPA in eyes and brain PL and gills NL; for DHA in WB, muscle, brain PL, and gills NL. Conversely 18:3n3 was higher in WB NL at 29 compared to $22^{\circ} \mathrm{C}$. Some diet $\mathrm{x}$ temperature interactions were noticed. In whole body NL EPA and DHA were significantly effected by temperature only in fish fed LD, but not in fish fed HD. Same interaction occurred for DHA in gills PL, in this case 22 LD fish had same DHA content than the HD groups. In eyes PL a more noticeable influence of temperature on EPA was observed in HD groups than in LD groups. Nervonic acid (24:1n-9) was also found at substantial amount in brain PL (3.3 to 3.7\% of total FA) without significant influence of the two studied factors.

The relative influences of the two diets and temperatures on tissues fatty acid content were summarized using D, distance coefficients (Table 2) calculated with all determined fatty acids. In fish PL, higher D values were observed between diets than between temperatures for all tissues, except brain. The diet impact was remarkably low in brain $(\mathrm{D}=1.8$ for each temperature), and moderate in eyes (3.1-4.4). Temperature impact was lower in eyes and liver than in other tissues. In NL, diet impact was strong for all tissues analysed and temperature impact was low, except for liver. Comparing these effects between treatments, FA tissues specificities were kept within each treatment. Distances were calculated between each tissue within each treatment, similar D values were obtained between 2 tissues whatever the treatments were. Table 3 summarized these results presented as mean values with variability between treatments $\left(\mathrm{S}^{\circ} \mathrm{E}^{\circ}\right)$ for same comparison. This method indicate NL fatty acid patterns were relatively similar in muscle, eyes and gills and close to whole body NL, while liver and brain NL differed strongly. PL fatty acid patterns were more specific of each tissue, a little less for muscle and gills compared to whole body PL.

\section{Discussion}

After a 84 day exposure of sea bass juveniles to the four experimental conditions tested ( 0.4 or $2.2 \% \mathrm{n}-3$ HUFA in diets $\mathrm{x} 22$ or $29^{\circ} \mathrm{C}$ water temperature), diet has a stronger effect on tissues FA profile than temperature. Whereas temperature had a rather stronger effect on growth performance than diets (Person-le Ruyet et al., 2004a). The effect of diets was expected as the fatty acid composition of fish tissues usually tend to reflect those of dietary lipids (Bell et al., 2001; Jobling, 2001). As it generally occurred, diet influence was higher in neutral lipids (more similar to dietary fatty acid pattern) than in polar lipids (Skalli and Robin, 2004). The relative higher levels of HUFAs as DHA EPA and AA in tissues PL compared to NL is in accordance with the preferential incorporation of these fatty acids in phospholipids (Linares and Henderson, 1991). In muscle, liver and gills, the LD diet (low n-3 HUFA content) induced higher levels of oleic (18:1n-9), linoleic (18:2n6 ) and linolenic (18:3n-3) acids in polar and neutral lipids than the HD diet and lower levels of n-3 HUFA. However, diet influence was particularly low in brain PL. It was also relatively low on eyes PL, that contained high DHA levels (not influenced by treatments). Then, even when fed a diet below the n-3 HUFA requirement (Skalli and Robin, 2004), fish tend to maintain functionality of neural and visual tissues, where DHA is of key importance (Lauritzen et al., 2001). On the same species Pagliarani et al. (1986) obtained a noticeable influence of vegetal oils on brain fatty acid content with a marked decrease of DHA in PL, 
but with diets more depleted in HUFA than LD here. DHA is known to be present at high levels in brain, and at very high levels in eyes of various fish species (Tocher and Harvie, 1988; Mourente, 2003).

In this experiment, high levels of saturates were observed in tissues compared to diets. Both palmitic (16:0) and stearic (18:0) acids were high especially in liver NL. These fatty acids were also present at high levels in polar lipids, as classically associated with HUFAs in diacyl phospholipids of fish (Bell and Dick, 1991). The high levels of tissue saturates, may result from a lipogenic activity (Dias et al., 1998). This finding is in agreement with the higher feed intake and feed conversion ratio of fish observed at $29^{\circ} \mathrm{C}$ than at $22^{\circ} \mathrm{C}$ (Person-Le Ruyet et al., 2004a). In sea bass juveniles, $29^{\circ} \mathrm{C}$ is a temperature close to the upper tolerance limit, the temperature for maximum growth being $26^{\circ} \mathrm{C}$

(Person-Le Ruyet et al., 2004b). Despite this apparent lipogenic activity reinforced at $29^{\circ} \mathrm{C}$, lipid liver content tended to be lower at 29 than at $22^{\circ} \mathrm{C}$, fatty acids produced in liver being mainly exported to other tissues; the main site of lipid storage in this species is perivisceral adipose tissue (Dias et al., 1998).

The higher level of 18:3n-6 in fish fed LD compared to HD, strongly suggests it was produced by desaturation of 18:2n-6, since 18:3n-6 content in LD diet was very low and 3 times lower than in HD diet. Other observations support this finding: i) the differences in $18: 3 n-6$ between dietary groups was marked in liver, a tissue known to be involved in desaturation-elongation activity; ii) in gill PL, high levels of 18:3n-6 were associated with high levels of 20:4n-6 (AA). Similar bio-conversion capacity stimulated by HUFA dietary deficiency have been shown in freshwater and marine fish species (Buzzi et al., 1996; Seiliez et al., 2001, 2003). In gill PL the 18:3n- 6 contents were lower at 29 than at $22^{\circ} \mathrm{C}$, corresponding to a reduced desaturation with an increase in temperature (Tocher and Sargent, 1990). It may also explain the interaction observed between diet and temperature on 20:4n-6 contents in gills, considering AA contents were both affected by dietary levels and by desaturation process. The highest level of AA observed in gill PL, underlines the importance of this FA for gill function (Henderson et al., 1985; anonymous, 1987; Bell et al., 1994 ). A desaturation-elongation process, enlightened by 18:3n-6 contents, may also contribute to maintain relatively high AA levels in phospholipid of fish fed LD despite the low AA content in this diet. However AA contents of all tissues PL remained significantly lower in LD groups than in HD groups. In this experiment, 18:3n-6 let to demonstrate a desaturation activity more clearly than FA of the n-3 series. Diets contained higher levels of intermediates and final products with lower precursors in n-3 than in n-6 FA. Similar biotransformations may also occurred in the n-3 series but cannot be evidenced.

The effect of temperature on fish fatty acid composition was less documented mainly regarding marine fish species. In European sea bass juveniles, adaptation to low temperature did not induce major change in polar lipid fatty acid composition of liver and heart (Trigari et al., 1992) or gill and kidney (Ventrella et al., 1993). The present study let to observe several significant influences of temperature on polar lipids of various tissues as previously shown on whole body fatty acid composition (Person-Le Ruyet et al., 2004a). In salmonids, thermal response corresponds to a higher proportion of unsaturated FA with low temperature (Hazel et al. 1992; Calabretti et al., 2003). Similar effects of temperature were observed in the present study, with lower saturates and 18:1n-9 versus higher n-3 FA 
contents at 22 than at $29^{\circ} \mathrm{C}$. Traditionally, a higher levels of n-3HUFA (DHA + EPA) in fish at low temperature was previously interpreted as a way to maintain membrane fluidity (homeoviscous regulation). This notion was denied by Sargent et al. (2002, pp. 197-198) who consider the intrinsic structure of 22:6n-3 is inherently resistant to temperature change, its abundance in fish diacyl phospholipids insuring membrane functionality independently to environmental variables. Another determinant of membrane fluidity can be the ratio of monounsaturated versus saturated fatty acids in diacyl phospholipids (Wodtke and Cossins, 1991). However present results did not let to observe such regulation as both saturates and monoenes were higher at 29 than at $22^{\circ} \mathrm{C}$. According to Poon et al. (1981), caution should be exercised in inferring changes in membrane fluidity based on lipid modulation of biological membranes.

Differences in fatty acid composition related to temperature depended also on the tissue examined. As shown in PL by distance coefficients, brain, gill and muscle were more affected by temperature than liver and eyes. The effect of temperature was different in gill than in brain and muscle, concerning 18:0 and n-3 FA. Major disparities between tissues with regard to the influence of temperature on FA composition occurred in the n- 6 series: at $29^{\circ} \mathrm{C} 18: 2 \mathrm{n}-6$ in PL was lower in muscle but higher in gill compared to $22^{\circ} \mathrm{C}$, and $20: 4 n-6$ in PL was higher in muscle and in gills (only for diet HD) but lower in brain. Differences in tissues composition should result from tissues specificities in fatty acid affinity and metabolism: high DHA versus low n-6 in eyes and brain; high AA contents in gills compared to other tissues. In this experiment, the more general temperature influence was encountered in saturates $(16: 0,18: 0)$ and 18:1n-9, for all tissues composition. These fatty acids are those produced by lipogenic activity, mainly in liver. Then part of observed differences could reflect an effect of temperature on fish energy metabolism, modifying available fatty acid pool. Inside this pool, fatty acids and mainly HUFAs were selectively retained for polar lipids. A more noticeable influence of temperature on PL than on NL tissue content suggest some relevance in terms of thermal adaptation. As feed intake was higher at $29^{\circ} \mathrm{C}$ than at $22^{\circ} \mathrm{C}$, higher n-3 HUFA quantities were ingested at 29 than at $22^{\circ} \mathrm{C}$. These quantities ingested failed to attenuate lack of n-3 HUFA in LD fed fish. In opposite, significant effect of temperature occurring in various tissues PL corresponded to lower n-3 HUFA content at 29 than at $22^{\circ} \mathrm{C}$, with the deficient HUFA diet as well as with the sufficient diet.

Muscle FA content was more similar to whole body FA content than other tissues. This seems logical as muscle represent the major part of fish. However the total lipid content was low in muscle compare to whole body. In this species most of NL are stored in perivisceral fat. Then muscle represent the major quantity of PL rather than NL on whole body basis. Within each dietary groups DHA and EPA levels were relatively similar in NL of all tissues analysed, except liver, while more specificities between tissues were observed in PL content. Comparison of tissues PL content let to show different responses to temperature and dietary HUFA between tissues. These responses should depend on the active roles of HUFA for each tissue functionality and on the capacity of each tissue to regulate its PL content in order to maintain this functionality. Among the tissues analysed, neural tissue (brain and eyes) had the highest regulation capacity inducing low diet influence on their PL content.

\section{References}

Alexis, M.N., 1997. Fish meal and fish oil replacers in Mediterranean marine fish diets. Cah. Options Mediterr. 22, 183-204. 
Anonymus, 1987. Potential importance of arachidonate in gill function of marine fish. Nutrition Reviews 45 (2), 58-60.

Bell, J.G., Tocher, D.R., MacDonald, F.M., Sargent, J.R., 1994. Effects of diets rich in linoleic $(18: 2 n-6)$ acid and linolenic $(18: 3 n-3)$ acids on the growth, lipid class and fatty acid compositions and eicosanoid production in juvenile turbot (Scophthalmus maximus). Fish Physiol. Biochem. 13, 105-118.

Bell, J.G., McEvoy, J., Tocher, D.R., McGhee, F., Campbell, P.J., Sargent, J.R., 2001. Replacement of fish oil with rapeseed oil in diets of atlantic salmon (Salmo salar) affects tissue lipid compositions and hepatocyte fatty acid metabolism. J. Nutr. 131, 1535-1543.

Bell, M.V., Dick, J.R., 1991. Molecular species composition of the major diacyl glycerophospholipids from muscle liver, retina and brain of cod (Gadus morhua). Lipids 26, 565-573.

Buzzi, M., Henderson, R.J., Sargent, J.R., 1996. The desaturation and elongation of linoleic acid and eicosapentaenoic acid by hepatocytes and liver microsomes from rainbow trout (Oncorhynchus mykiss) fed diets containing fish oil or olive oil. Biochim. Biophys. Acta $1299,235-244$.

Calabretti, A., Cateni, F., Procida, G., Favretto, L.G., 2003. Influence of environmental temperature on composition of lipids in edible flesh of rainbow trout (Oncorhynchus mykiss). J. Sci. Food Agric. 83, 1493-1498.

Dias, J., Alvarez, M.J., Diez, A., Corraze, G., Bautista, J.M., Kaushik, S.J., 1998.

Regulation of hepatic lipogenesis by dietary protein/energy in juvenile European seabass (Dicentrarchus labrax). Aquaculture 161, 169-186.

Farkas, T., Dey, I., Buda, C.S., Halver, J.E., 1994. Role of phospholipid molecular species in maintaining lipid membrane structure in response to temperature. Biophys. Chem. 50, 147-155.

Folch, J., Lees, M., Stanley, G.H.S., 1957. A simple methods for the isolation and purification of total lipids from animal tissues. J. Biol. Chem. 226, 497-509.

Hazel, J.R., McKinley, S.J., Williams, E.E., 1992. Thermal adaptation in biological membranes: Interacting effects of temperature and pH. J. Comp. Physiol. B162, 593601, 1992.

Henderson, R.J., Bell, M.V., Sargent, J.R., 1985. The conversion of polyunsaturated fatty acids to prostaglandins by tissue homogenates of the turbot Scophthalmus maximus L. J. Exp. Mar. Biol. Ecol. 85, 93-99.

Izquierdo, M.S., Obach, A., Arantzamendi, L., Montero, D., Robaina, L., Rosenlund, G., 2003. Dietary lipid sources for seabream and seabass: growth performance, tissue composition and flesh quality. Aquacult. Nutr. 9, 397-407.

Jobling, M., 2001. Nutrient partitioning and the influence of feed composition on body composition. In: Houlihan, D., Boujard, T., Jobling, M. (Eds.). Food Intake in Fish. Blackwell, Oxford, pp. 354-375.

Juaneda, P., Rocquelin, G., 1985. Rapid and convenient separation of phospholipids and non-phosphorus lipids from rat heart using silica cartridges. Lipids 20, 40-41. 
Kanazawa, A., Teshima, S.I., Ono, K., 1979. Relationship between essential fatty acid requirements of aquatic animals and the capacity for bioconversion of linolenic acid to highly unsaturated fatty acids. Comp. Biochem. Physiol. 63B,295-298.

Lauritzen, L., Hansen, H.S., Jorgensen, M.H., Michelsen, K.F., 2001. The essentiality of n3 fatty acids in relation to development and function of the brain and retina. Prog. Lipid Res. 40, 1-94.

Linares, F., Henderson, R.J., 1991. Incorporation of 14C-labelled polyunsaturated fatty acids by juvenile turbot, Scophthalmus maximus (L.) in vivo. J. Fish Biol. 38 , 335-347.

McIntire, C.D., Tinsley, I.J., Lowry, R.R., 1969. Fatty acids in lotic periphyton: another measure of community structure. J. Phycol. 5, 26-32.

Morrison, W., Smith, L., 1964. Preparation of fatty acid methyl esters and dimethylacetals from lipids with boron fluoride-methanol. J. Lipid Res. 5, 600-608.

Mourente, G., 2003. Accumulation of DHA (docosahexaneoic acid, 22:6n-3) in larval and juvenile fish brain. In: Browman, H.I., Skiftesvik, A.B. (Eds.), The Big Fish Bang, Proceedings of the 26th Ann. Larval Fish Conference. Institute of Marine Research, Bergen Norway, pp 239-248.

Pagliarani, A., Pirini, M., Trigari, G., Ventrella, V., 1986. Effects of diets containing different oils on brain fatty acid composition in sea bass (Dicentrarchus labrax). Comp. Biochem. Physiol. 83 B, 277-282.

Person-Le Ruyet, J., Skalli, A., Dulau, B., Le Bayon, N., Le Delliou, H., Robin, J.H., 2004a. Does dietary n-3 highly unsaturated fatty acids level influence the European sea bass (Dicentrarchus labrax)capacity to adapt to a high temperature? Aquaculture 242, 571-588.

Person-Le Ruyet, J., Mahé, K., Le Bayon, N., Le Delliou, H., 2004b. Effects of temperature on growth and metabolism in a Mediterranean population of European sea bass, Dicentrarchus labrax. Aquaculture 237, 269-280.

Poon, R., Richards, J.M., Clark, W.R., 1981. The relationship between plasma membrane lipid composition and physical-chemical properties. II Effect of phospholipid fatty acid modulation on plasma membrane physical properties and enzymatic activities. Biochem. Biophys. Acta 649, 58-66.

Regost, C., Arzel, J., Robin, J., Rosenlund, G., Kaushik, S.J., 2003. Total replacement of fish oil by soybean oil or linseed oil with return to fish oil in turbot (Psetta maxima). 1 growth performance, flesh fatty acid profile, and lipid metabolism. Aquaculture 217, 465-482.

Robertson, J.C., Hazel, J.R., 1996. Membranes constraints to physiological function at different temperatures; does cholesterol stabilize membranes at elevated temperatures? In: Woods, C.M., McDonald, D.G. (Eds.), Society for experimental biology, seminar series 61: Global warming: implications for freshwater and marine fish. Cambridge University Press, pp 25-49.

Sargent, J.R., Tocher, D.R., Bell, J.G., 2002. The lipids. In: Halver, J.E., Hardy, R.W. (Eds.). Fish Nutrition. Academic Press, New York, pp. 181-257.

Seiliez, I., Panserat, S., Kaushik, S., Bergot, P., 2001. Cloning, tissue distribution and nutritional regulation of a $\Delta 6$-desaturase-like enzyme in rainbow trout. Comp. Biochem. Physiol. 130 B, 83-93.

Seiliez, I., Panserat, S., Corraze, G., Kaushik, S., Bergot, P., 2003. Cloning and nutritional regulation of a $\Delta 6$-desaturase-like enzyme in the marine teleost gilthead seabream (Sparus aurata). Comp. Biochem. Physiol. 135 B, 449-460. 
Skalli, A., Robin, J.H., 2004. Requirement of n-3 long chain polyunsaturated fatty acids for European sea bass (Dicentrarchus labrax) juveniles: growth and fatty acid composition. Aquaculture 240, 399-415.

Staurnes, M., Rainuzzo, J.R., Sigholt, T., Joergensen, L., 1994. Acclimation of Atlantic cod (Gadus morhua) to cold water. Stress response, osmoregulation, gill lipid composition and gill Na-K-ATPase activity. Comp. Biochem. Physiol. 109A, 413-421.

Tocher, D.R., 2003. Metabolism and functions of lipids and fatty acids in teleost fish. Rev. Fish. Sci. 11, 107-184.

Tocher, D.R., Harvie, D.G., 1988. Fatty acid compositions of the major phosphoglycerides from fish neural tissues; (n-3) and (n-6) polyunsaturated fatty acids in rainbow trout (Salmo gardneri) and cod (Gadus moruhua) brains and retinas. Fish Physiol. Biochem. 5, 229-239.

Tocher, D.R., Sargent, J.R., 1990. Effect of temperature on the incorporation into phospholipid classes and metabolism via desaturation and elongation of n-3 and n-6 polyunsaturated fatty acids in fish cells in culture. Lipids $25,435-442$.

Trigari, G., Pirini, M., Ventrella, V., Pagliarani, A., Trombetti, F., Borgatti, A.R., 1992. Lipid composition and mitochondrial respiration in warm- and cold-acclimated sea bass (Dicentrarchus labrax L.). Lipids 27, 371-377.

Ventrella, V., Pagliarani, A., Pirini, M., Trigari, G., Trombetti, F., Borgatti, A.R., 1993. Lipid composition and microsomal ATPase activities in gills and kidneys of warm and cold acclimated sea bass (Dicentrarchus labrax L.). Fish Physiol. Biochem. 12, 293-304.

Wodtke, E., Cossins, A.R., 1991. Rapid cold-induced changes of membrane order and delta-9-desaturase activity in endoplasmic reticulum of carp liver: A time-course study of thermal adaptation. Biochim. Biophys. Acta 1064, 343-350. 
Table 1. Total lipid content of the various tissues (\% wet weight basis \pm SE), data on whole body lipid content reported from Person-Le Ruyet et al. (2004a).

\begin{tabular}{lccccccc}
\hline & \multicolumn{3}{c}{ Treatment } & \multicolumn{3}{c}{2 way ANOVA } \\
\cline { 2 - 9 } & $22-\mathrm{HD}$ & $22-\mathrm{LD}$ & $29-\mathrm{HD}$ & $29-\mathrm{LD}$ & Diet & $\mathrm{T}^{\circ}$ & $\mathrm{D}$. \\
\hline Whole body & $16.3 \pm 0.7$ & $17.1 \pm 0.5$ & $18.1 \pm 0.4$ & $18.4 \pm 0.6$ & $\mathrm{~ns}$ & $\mathrm{~ns}$ & $\mathrm{~ns}$ \\
Muscle & $3.0 \pm 0.2$ & $3.9 \pm 1.1$ & $4.7 \pm 1.2$ & $3.8 \pm 0.1$ & $(\mathrm{~ns})$ & $(\mathrm{ns})$ & $(\mathrm{ns})$ \\
Liver & $40.1 \pm 3.8 \mathrm{a}$ & $40.3 \pm 2.6 \mathrm{a}$ & $28.6 \pm 1.6 \mathrm{~b}$ & $35.4 \pm 2.2 \mathrm{ab}$ & $\mathrm{ns}$ & $*$ & $* * *$ \\
Gills & $3.2 \pm 0.2$ & $3.5 \pm 0.2$ & $3.3 \pm 0.2$ & $3.3 \pm 0.2$ & $\mathrm{~ns}$ & $\mathrm{~ns}$ & $\mathrm{~ns}$ \\
Eyes & $10.1 \pm 0.6$ & $8.5 \pm 0.6$ & $9.5 \pm 0.4$ & $8.6 \pm 0.6$ & $\mathrm{~ns}$ & $\mathrm{~ns}$ & $\mathrm{~ns}$ \\
Brain & $9.4 \pm 0.5$ & $9.7 \pm 0.2$ & $9.7 \pm 0.4$ & $10.4 \pm 1.0$ & $\mathrm{~ns}$ & $\mathrm{~ns}$ & $\mathrm{~ns}$ \\
\hline
\end{tabular}

Values are means \pm standard error $(\mathrm{n}=3) .2$ way ANOVA statistical results: $* \mathrm{P}<0.05$; *** $\mathrm{P}<0.001$; ns: not significant; (ns) unequal variances, rank test analysis. In case of significant interaction means having different superscript letter in the same raw are significantly different (Newmann-Keuls test, $\mathrm{P}<0.05$ )

Table 2. Comparison of fatty acid profiles by McIntyre distance coefficient (D).

\begin{tabular}{|c|c|c|c|c|c|}
\hline & Muscle & Liver & Gills & Eyes & Brain \\
\hline \multicolumn{6}{|l|}{ Polar lipids } \\
\hline \multicolumn{6}{|c|}{ Among temperatures within a diet: } \\
\hline 22-HD/29-HD & 4.8 & 2.2 & 5.2 & 1.6 & 4.6 \\
\hline 22-LD/29-LD & 4.4 & 2.6 & 5.1 & 2.6 & 4.4 \\
\hline \multicolumn{6}{|c|}{ Among diets within a temperature: } \\
\hline 22-HD/22-LD & 11.4 & 9.8 & 8.1 & 4.4 & 1.8 \\
\hline 29-HD/29-LD & 10.4 & 9.3 & 9.0 & 3.1 & 1.8 \\
\hline \multicolumn{6}{|l|}{ Neutral lipids } \\
\hline \multicolumn{6}{|c|}{ Among temperatures within a diet: } \\
\hline 22-HD/29-HD & 1.7 & 7.1 & 1.6 & 0.9 & 2.5 \\
\hline 22-LD/29-LD & 0.7 & 6.9 & 2.7 & 0.9 & 3.1 \\
\hline \multicolumn{6}{|c|}{ Among diets within a temperature } \\
\hline 22-HD/22-LD & 12.9 & 12.2 & 12.4 & 12.7 & 10.7 \\
\hline 29-HD/29-LD & 12.4 & 9.8 & 13.4 & 12.3 & 9.5 \\
\hline
\end{tabular}


Table 3. Crossed comparison between tissues : Distance (McIntyre distance coefficient : D) between the each tissues and whole body (WB) fatty acid pattern, in neutral lipids (NL upper right part) and polar lipids (lower left part) were calculated for each treatment, mean values ( \pm ES between treatments)

\begin{tabular}{lccccccc}
\hline & WB & Muscle & Liver & Gills & Eyes & Brain \\
\hline WB & & $\mathbf{1 . 6 ( 0 . 3 )}$ & $\mathbf{1 4 . 0 ( 0 . 9 )}$ & $\mathbf{4 . 3 ( 0 . 4 )}$ & $\mathbf{2 . 1 ( 0 . 3 )}$ & $\mathbf{1 5 . 9 ( 0 . 5 )}$ & \\
Muscle & $7.0(0.4)$ & & $\mathbf{1 4 . 1 ( 1 . 2 )}$ & $\mathbf{3 . 3 ( 0 . 7 )}$ & $\mathbf{1 . 7 ( 0 . 1 )}$ & $\mathbf{1 5 . 2 ( 1 . 1 )}$ & \\
Liver & $13.2(1.4)$ & $9.9(2.7)$ & & $\mathbf{1 5 . 2 ( 1 . 8 )}$ & $\mathbf{1 5 . 1 ( 1 . 3 )}$ & $\mathbf{2 2 . 8 ( 1 . 4 )}$ & $\mathbf{N}$ \\
Gills & $6.7(0.9)$ & $10.2(2.4)$ & $14.2(2.5)$ & & $3.5(\mathbf{0 . 7})$ & $\mathbf{1 2 . 6 ( 1 . 4 )}$ & $\mathbf{L}$ \\
Eyes & $26.0(1.7)$ & $21.8(3.4)$ & $15.1(1.5)$ & $27.5(2.4)$ & & $\mathbf{1 5 . 3 ( 1 . 2 )}$ \\
Brain & $12.4(0.4)$ & $14.1(1.6)$ & $18.1(2.9)$ & $15.1(1.2)$ & $24.5(2.1)$ & \\
& \multicolumn{7}{c}{ Polar lipids } \\
\hline
\end{tabular}




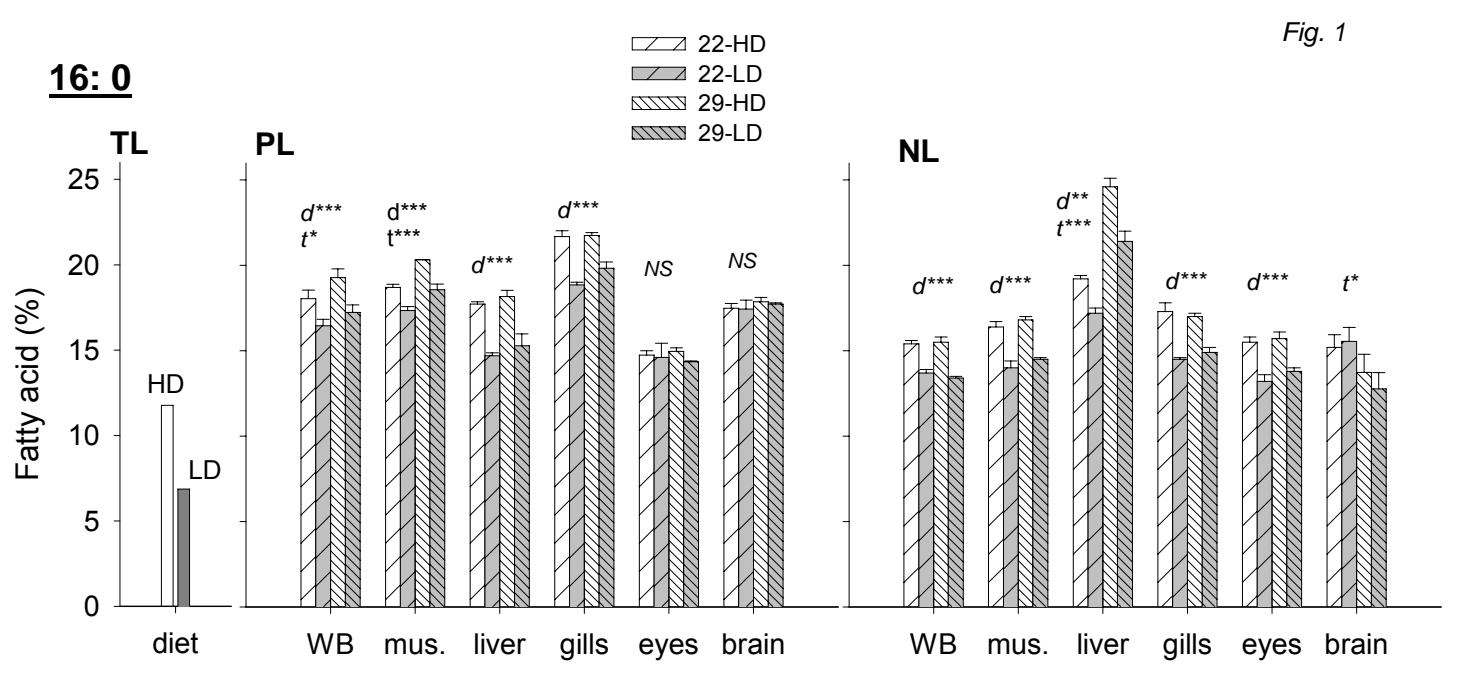

18: 0

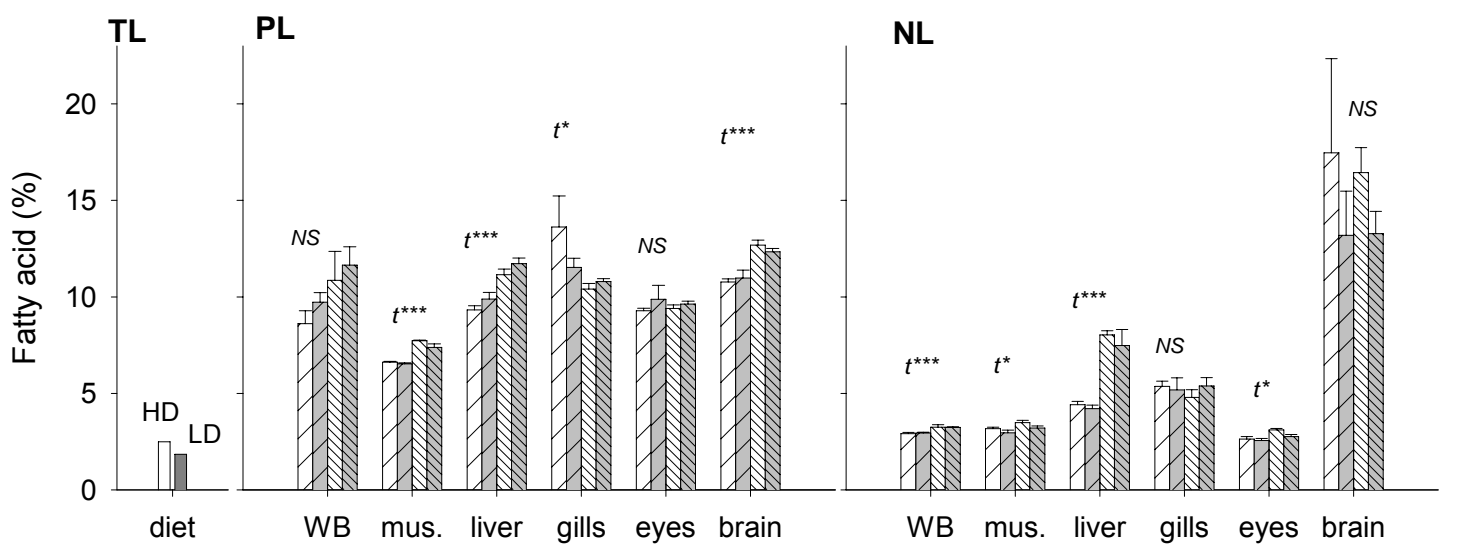

18: $1 \mathrm{n}-9$

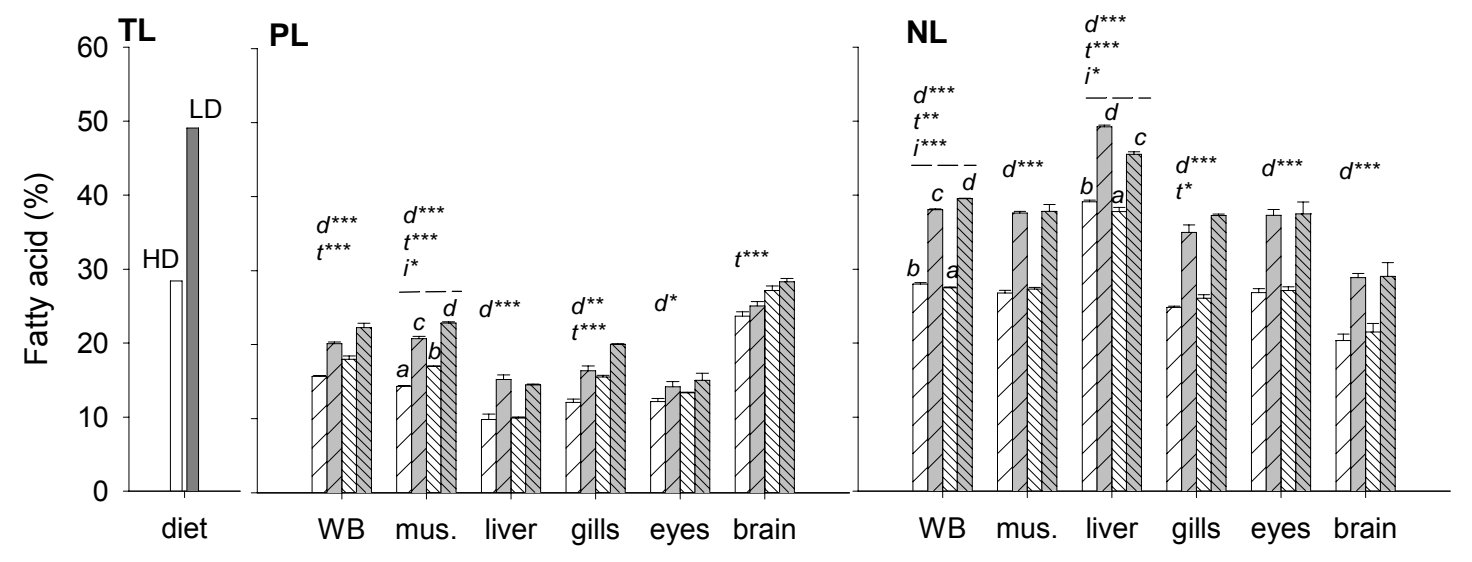

Fig.1- Changes in composition of main saturated and monounsaturated fatty acids (16:0, 18:0 and 18:1n-9, respectively) of PL and NL fractions in whole body (WB) and different tissues studied. Means are given with standard error ( $n=3$ replicates). Letters $t$ and $d$ indicate significant statistical differences between temperature and diets: ${ }^{*}, \mathrm{P}<0.05$; ${ }^{* *}, \mathrm{P}<0.01$ and ${ }^{* *}, \mathrm{P}<0.001$. NS = no significant difference $(p \geq 0.05)$. Letter $i$ indicates interaction between the two factors, bars with different superscript letters are significantly different (Newmann-Keuls test, $\mathrm{P}<0.05$ ). 


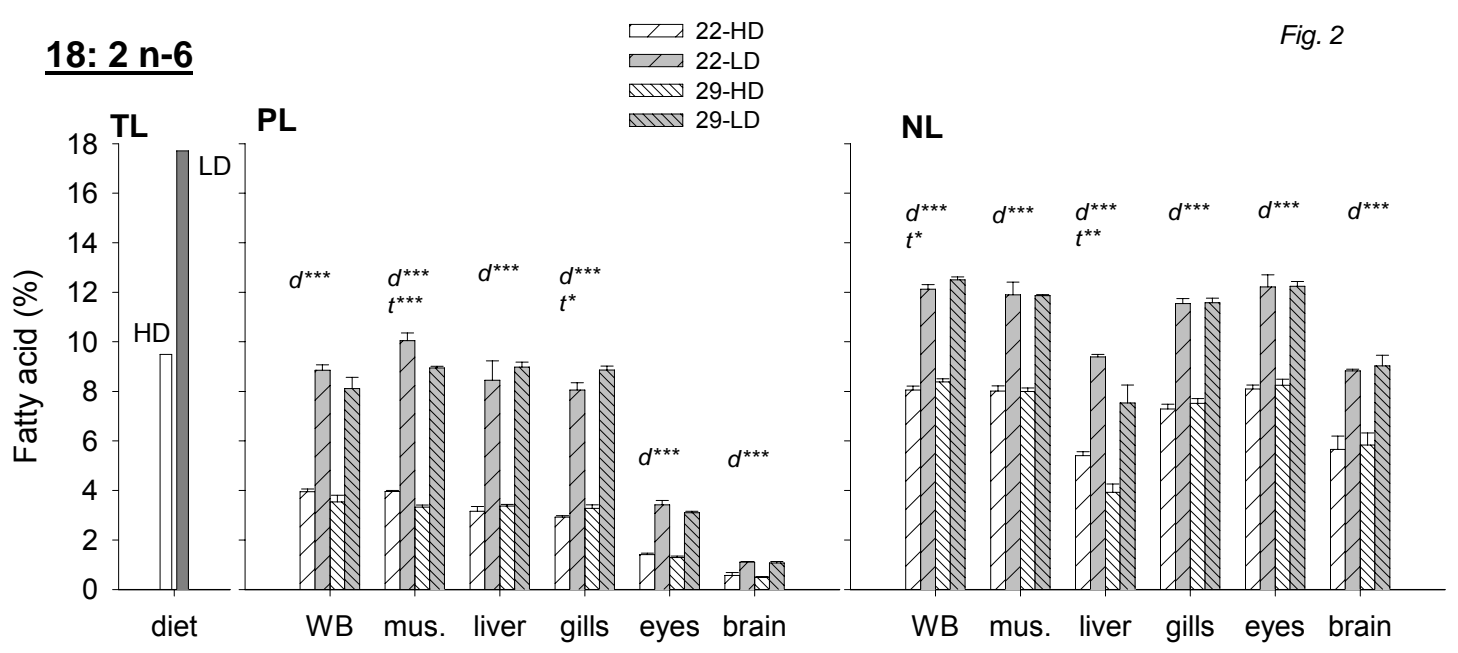

18: 3 n-6

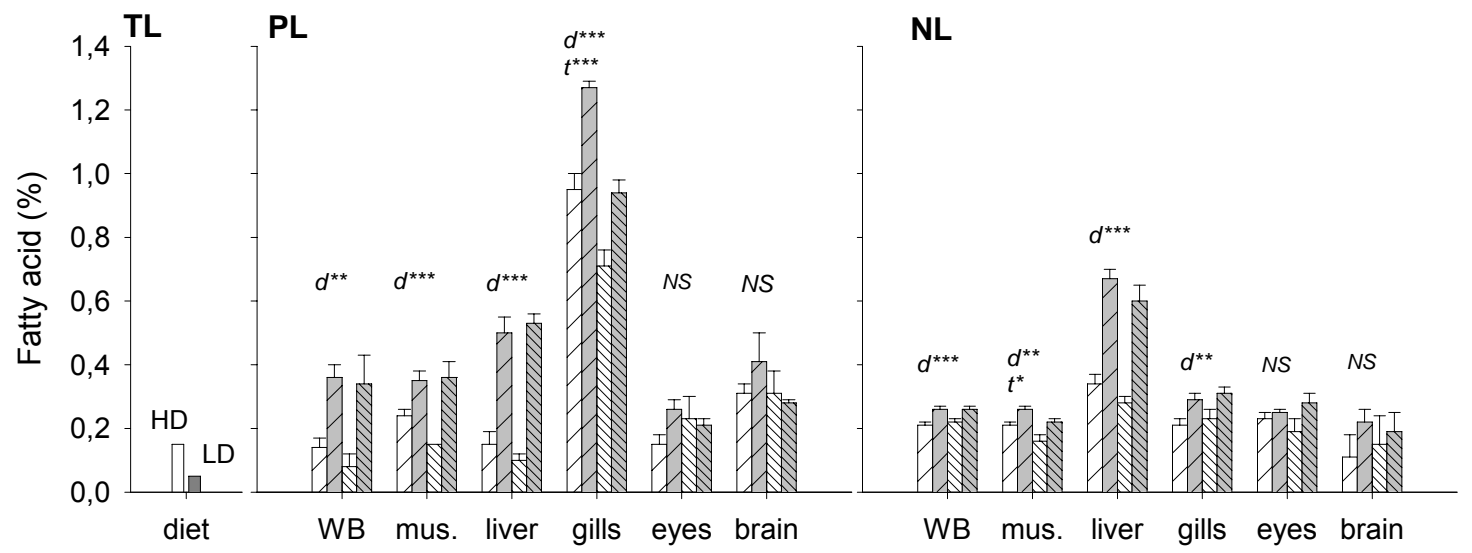

20: $4 n-6$

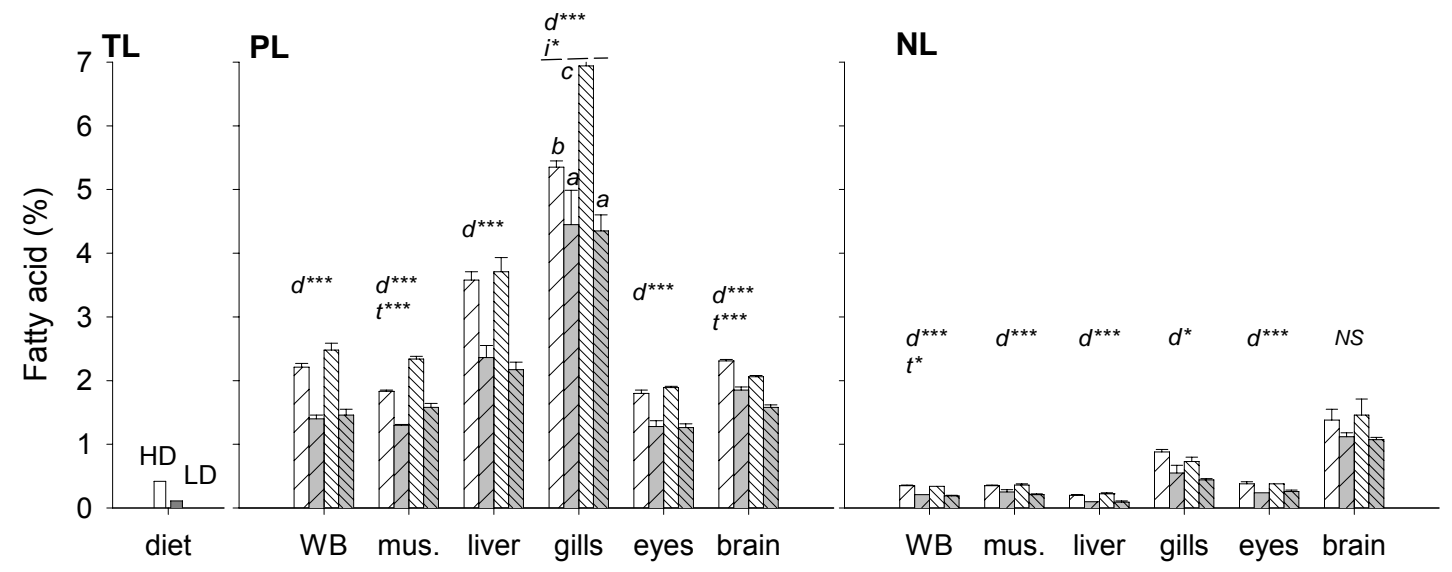

Fig.2- Changes in composition of 18:2n-6, 18:3n-6 and 20:4n-6 of PL and NL fractions in WB and different tissues studied. Means are given with standard error $(\mathrm{n}=3$ replicates). Letters $t$ and $d$ indicate significant statistical differences between temperature and diets: ${ }^{*}, \mathrm{P}<0.05 ;{ }^{* *}, \mathrm{P}<0.01$ and ${ }^{* * *}, P<0.001$. NS $=$ no significant difference $(p \geq 0.05)$. Letter $i$ indicates interaction between the two factors, bars with different superscript letters are significantly different (Newmann-Keuls test, $\mathrm{P}<0.05)$. 


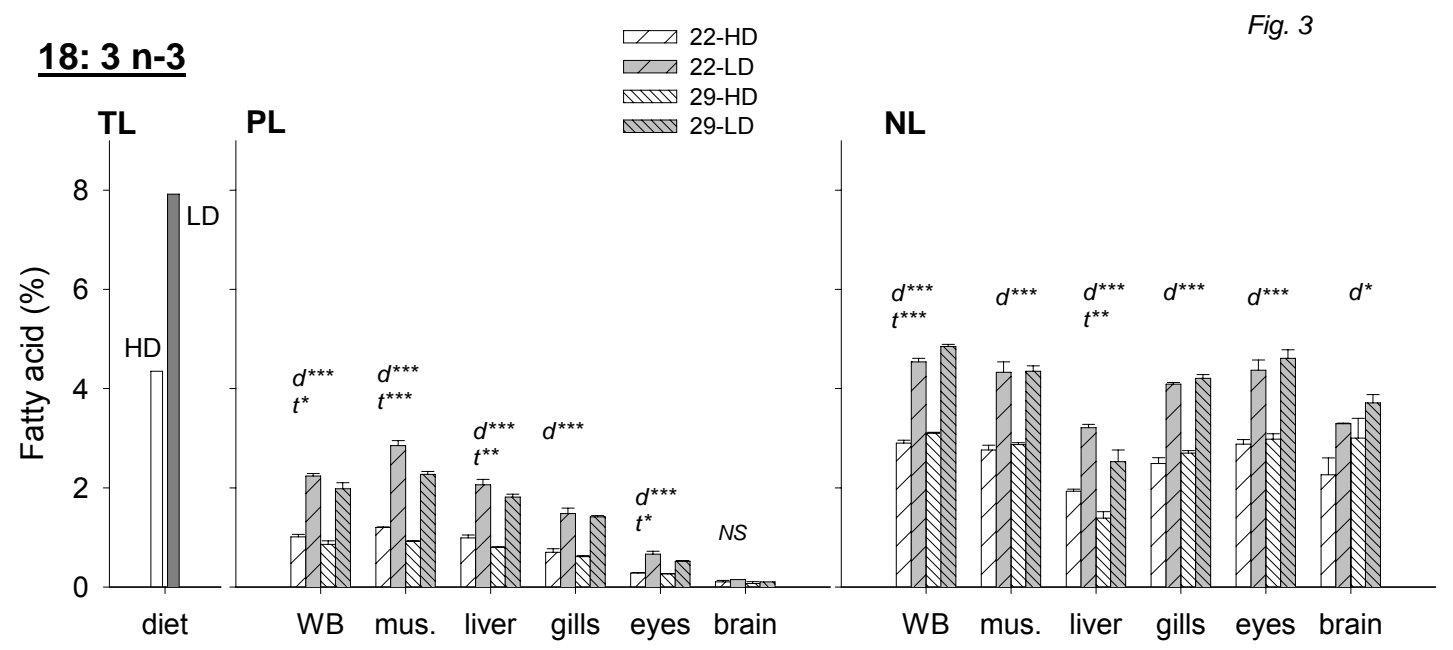

\section{0: $5 \mathrm{n}-3$}

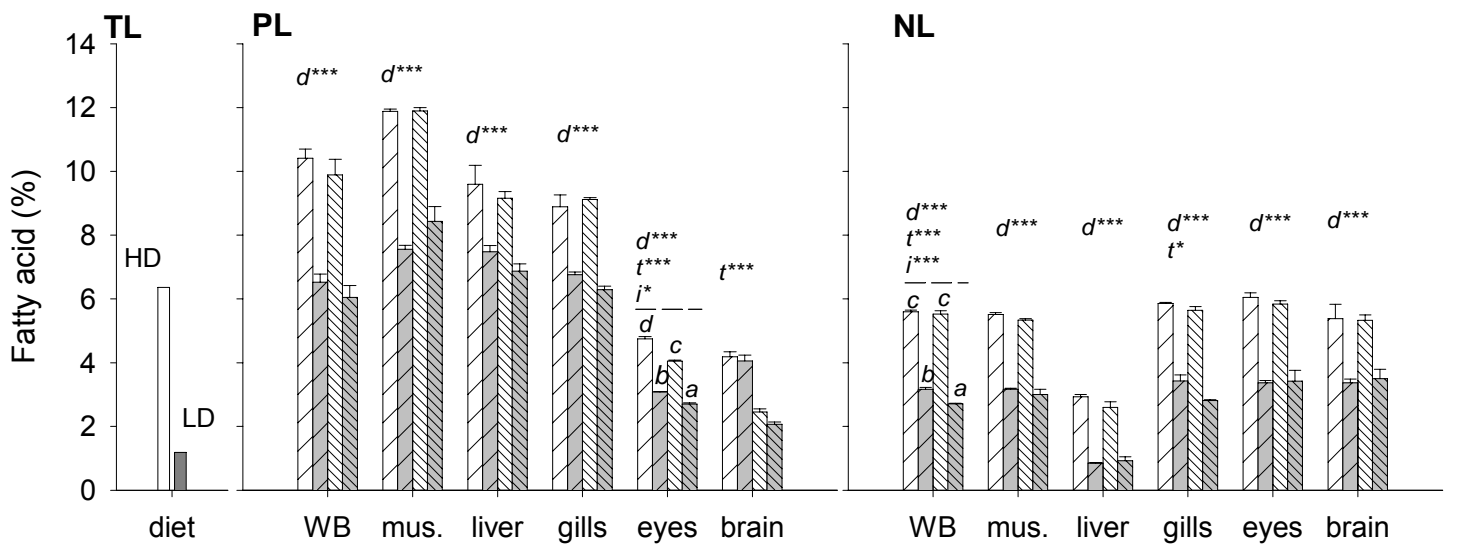

\section{2: $6 \mathrm{n}-3$}

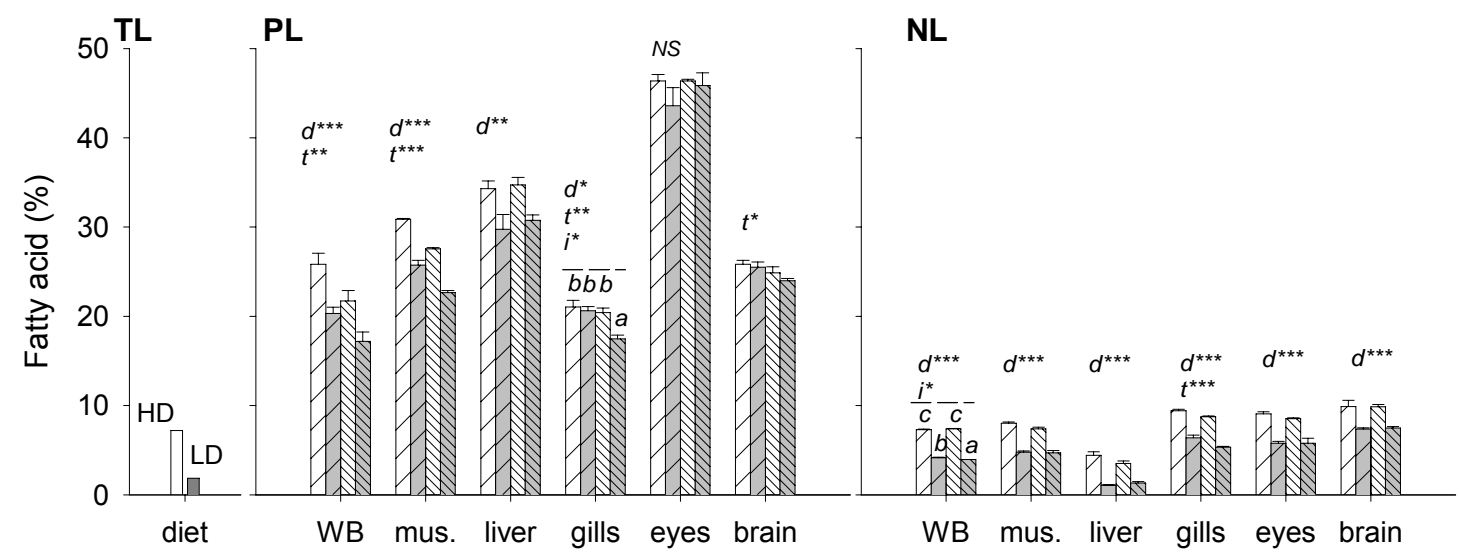

Fig. 3- Changes in composition of 18:3n-3, 20:5n-3 and 22:6n-3 of PL and NL fractions in WB and different tissues studied. Means are given with standard error $(n=3$ replicates). Letters $t$ and $d$ indicate significant statistical differences between temperature and diets: ${ }^{*}, \mathrm{P}<0.05$; ${ }^{* *}, \mathrm{P}<0.01$ and ${ }^{* * *}, P<0.001$. NS $=$ no significant difference $(p \geq 0.05)$. Letter $i$ indicates interaction between the two factors, bars with different superscript letters are significantly different (Newmann-Keuls test, $\mathrm{P}<0.05)$. 